DOI 10.4467/25439561KSR.21.002.14413

JAN STRADOMSKI https://orcid.org/0000-0002-7318-6534

Uniwersytet Jagielloński

Kraków

\title{
IDEA UNII KOŚCIELNEJ CZY JEDNOŚCI KOŚCIOŁA? O POLISEMANTYCZNOŚCI DYSKURSU W POLSKO-RUSKIEJ POLEMICE RELIGIJNEJ W DAWNEJ RZECZYPOSPOLITEJ (2. POŁ. XVI-XVII W.)
}

\author{
THE CONCEPT OF CHURCH UNION OR CHURCH UNITY? \\ ON THE POLYSEMANTIC NATURE OF DISCOURSE IN THE POLISH- \\ -RUTHENIAN RELIGIOUS POLEMICS IN THE POLISH-LITHUANIAN \\ COMMONWEALTH ( $2^{\mathrm{ND}}$ HALF OF THE $16^{\mathrm{TH}}-17^{\mathrm{TH}}$ CENTURY)
}

\section{Streszczenie}

Kontrowersje dotyczące proklamacji i skutków unii brzeskiej (1596) znalazły odbicie w bogatej literaturze historycznej, polemicznej i religijnej, jaka powstała na terenie Rzeczypospolitej Obojga Narodów na przestrzeni kilkunastu dziesięcioleci (2. poł. XVI-XVII w.). Gorący spór toczył się pomiędzy przedstawicielami Kościoła rzymskokatolickiego, greckokatolickiego oraz prawosławnego. W artykule zwrócono uwagę na posługiwanie się przez każdą ze stron tego religijno-politycznego konfliktu podobnymi argumentami, którym jednakże podstawiano różne znaczenia w zależności od odmiennych perspektyw eklezjologicznych i historyczno-kulturowych autorów wypowiedzi. W ten sposób polemika religijna stała się w praktyce dyskusją skierowaną w stronę utrwalania stanowiska przedstawicieli własnego obozu, a nie pozyskiwania zwolenników ze strony przeciwnej.

\section{Abstract}

Controversies regarding the proclamation and the consequences of the Union of Brest (1596) were reflected in extensive historical, polemical and religious literature that was 
created in the Commonwealth of Both Nations over several decades ( 2 nd half of the $16^{\text {th }}-17^{\text {th }}$ century). There was a heated dispute between the representatives of the Roman Catholic, Greek Catholic and Orthodox Churches. The article highlights the use of similar arguments by each of the parties to this religious-political conflict which, however, were given different meanings depending on various ecclesiological, historical and cultural perspectives of the authors of a statement. Thus, in practice, religious polemics became a discussion aimed at strengthening the position of representatives of one's own party, instead gaining supporters among opponents.

Słowa kluczowe: literatura religijna, polemika religijna, eklezjologia, schizma kościelna, unia brzeska

Keyw ords: religious literature, religious polemics, ecclesiology, Church schism, The Union of Brest

Zawarta w Rzymie w przeddzień Wigilii Bożego Narodzenia 1595 roku, a następnie proklamowana niespełna rok później (9 października 1596 r.) w Brześciu nad Bugiem unia kościelna pomiędzy Kościołem rzymskokatolickim i ruską Cerkwią prawosławną należy do tych wydarzeń, których skutki odczuwalne były przez następne stulecia nie tylko w granicach Rzeczypospolitej, ale również poza nimi ${ }^{1}$. Przypomnijmy tylko, że ten kościelny akt zjednoczenia uznała tylko część prawosławnego episkopatu ruskiego i wyższego duchowieństwa, natomiast duchowieństwo parafialne i środowiska monastyczne wraz z większością wiernych stanowczo go oprotestowały. Mając jednakże poparcie oficjeli Kościoła rzymskiego oraz króla polskiego Zygmunta III Wazy unia weszła w życie niemal natychmiast, wprowadza-

${ }^{1}$ Dzieje unii brzeskiej i jej znaczenie w historii Rzeczypospolitej oraz krajów ościennych zostały omówione w ogromnej liczbie opracowań, dlatego praktyką staje się odsyłanie do prac względnie najnowszych, gdzie można znaleźć omówienia dotychczasowego stanu badań oraz szczegółową bibliografię. Z ciekawszych opracowań ostatnich dwóch dekad warto odnotować: М.В. Дмитриев, Между Римом и Царьградом. Генезис Брестской иерковной унии 1595-1596 г2., Москва, Издательство Московского Государственного Университета, 2003; Л. Тимошенко, Берестейська унія 1596 р., Дрогобич, Дрогобицький державний педагогічний університет ім. I. Франка, 2004; J. Moskałyk, Problem zjednoczenia $w$ Kościele kijowskim w I połowie XVII wieku, Poznań, Uniwersytet Adama Mickiewicza. Wydział Teologiczny. Redakcja Wydawnictw, 2006; A. Gudziak, Kryzys i reforma. Metropolia kijowska, patriarchat Konstantynopola i geneza unii brzeskiej, tłum. H. Leskiw, A. Chrin, Lublin, Wydawnictwo Uniwersytetu Marii Curie-Skłodowskiej, 2008 (wydanie ang.: Cambridge (Mass.) 1998); Dziedzictwo unii brzeskiej, red. R. Dobrowolski, M. Zemło, Lublin, Supraśl, Wydawnictwo KUL, Collegium Suprasliense, 2012; R. Czupryk, Unia brzeska: dzieło kościelnej jedności: retrospekcja historyczna, Sandomierz, Rzeszów, Rafał Czupryk, 2015; Unia brzeska: wybór źródel, wyboru tekstów dokonał M. Melnyk, thum. i oprac. M. Melnyk, W. Pilipowicz, Olsztyn, Katedra Aksjologicznych Podstaw Edukacji. Wydział Nauk Społecznych. Uniwersytet Warmińsko-Mazurski, 2016; Unia brzeska i jej konsekwencje. W 420 rocznicę synodu unijnego, red. A. Krochmal, A. Nowak, Przemyśl, Archiwum Państwowe, 2017. 
jąc do i tak złożonej już struktury etniczno-religijnej państwa polsko-litewskiego nowy element w postaci grekokatolików, czyli unitów. Trzeba nadmienić, iż zapisy brzeskiego porozumienia zostały przygotowane w taki sposób, by po ratyfikacji aktu unii w Rzeczypospolitej istniała już tylko jedna Cerkiew obrządku wschodniego greckokatolicka. W rozumieniu przepisów prawa formalnie zdelegalizowane więc zostało prawosławie, mimo iż de facto nadal istniało na dotychczasowych terenach. W życiu religijnym i politycznym państwa rozpętała się burza, a niepokoje społeczne były na tyle dotkliwe, że władza świecka musiała podejmować kroki zaradcze służące uspokojeniu nastrojów. Promując zawarte w Brześciu porozumienie, rządzący przymykali oko na protestacje prawosławnych hierarchów i wiernych z nadzieją, że i ci z czasem też przystapią do unii. Oczekiwania te okazały się jednak w dużej mierze płonne, a przynajmniej proces greckokatolickiej konwersji nie następował tak ochoczo i powszechnie, jak się tego spodziewano w Rzymie czy Warszawie. Co więcej, w czasach panowania króla Władysława IV Cerkiew prawosławna zdołała nawet odzyskać nieco swój stan posiadania i zaistnieć znów formalnie jako oficjalna instytucja w Rzeczypospolitej ${ }^{2}$. Dzieje i konsekwencje soboru brzeskiego wybiegają daleko poza problematykę aktów ogłoszonych w Rzymie i Brześciu. Nie miejsce tu, by zajmować się nimi w czysto historycznym ujęciu; ten aspekt zresztą został już dość dobrze zbadany. Wyjątkowość tamtejszych wydarzeń wynika z faktu, iż kontrowersje dotyczące warunków zawarcia unii, a przede wszystkim jej bliskoi dalekosiężnych skutków, wywołały zażarty dyskurs polemiczny, który trwał w katolicko-unicko-prawosławnym środowisku na przestrzeni bez mała dwóch stuleci, a zaowocował przynajmniej setką dzieł literackich ${ }^{3}$. Zwykle były to dość pokaźnych rozmiarów książki i traktaty, pisane i publikowane w językach ruskim (staroukraińskim i starobiałoruskim), cerkiewnosłowiańskim, polskim i łacińskim przez reprezentantów wszystkich spierających się stron, włączając w to również wspierających niekiedy sprawy Cerkwi ruskiej protestantów.

${ }^{2}$ A. Mironowicz, Podlaskie ośrodki i organizacje prawosławne w XVI i XVII wieku, Białystok, Dział Wydawnictw Filii UW, 1991, s. 144; Idem, Prawosławie i unia za panowania Jana Kazimierza, Białystok, Orthdruk, 1997, ss. 53-59.

${ }^{3} \mathrm{Na}$ temat polsko-ruskiego piśmiennictwa religijnego i polemicznego w tym okresie zob. m.in.: A. Naumow, Domus divisa. Studia nad literatura ruskq w I Rzeczypospolitej, Kraków, „Collegium Columbinum”, 2002; Idem, Święci Cyryl i Metody w polemice wyznaniowej, [w:] Środkowoeuropejskie dziedzictwo cyrylo-metodiańskie. Międzynarodowa konferencja naukowa, red. A. Barciak, Katowice, Societas Scientiis Silesiae Superioris - Instytut Górnośląski, ss. 173-184; J. Stradomski, Spory o ,wiaręgrecka” w dawnej Rzeczypospolitej, Kraków, Wydawnictwo „Scriptum”, 2003; Idem, Spór o historię $i$ wartości w świetle katolicko-unicko-prawosławnej polemiki religijnej w Pierwszej Rzeczypospolitej (koniec XVI - poczatek XVIII wieku), [w:] Między Wschodem a Zachodem. Prawostawie i unia, red. M. Kuczyńska, seria: Kultura Pierwszej Rzeczypospolitej w dialogu z Europa. Hermeneutyka wartości, t. XI, Warszawa, Wydawnictwa Uniwersytetu Warszawskiego, 2017, ss. 238-276 (w każdej pracy obszerna literatura przedmiotu). 


\section{Polemiczność dyskursu}

Dyskusja nie dotyczyła tylko i wyłącznie aktu unii brzeskiej, choć oczywiście była nią inspirowana i bardzo często formalnie jej dotyczyła. W rzeczywistości spór szedł jednak o kwestie bardziej ogólne, dotyczące modelu Kościoła powszechnego, jego struktury i funkcjonowania, a zwłaszcza charakteru i zakresu władzy najwyższych hierarchów. Można zatem powiedzieć, że chodziło tu nie tyle o naturę Kościoła, co o szeroko rozumianą politykę kościelną, z jej dogmatycznymi, obrzędowymi, jurysdykcyjnymi i obyczajowymi konsekwencjami. Na dziesiątkach tysięcy stron poruszono rozległy repertuar problematyki teologicznej, liturgicznej, obyczajowej, historycznej i prawnej, jaki różnił świat chrześcijaństwa wschodniego i zachodniego już od wieków. Unia była więc tylko pretekstem do wybuchu kontrowersji, która targała Kościołem przynajmniej od czasów wielkiej schizmy (1054), a nawet znacznie wcześniej. Fakt rozpadu Kościoła i opłakanych tego konsekwencji był dla wszystkich oczywisty, natomiast recepcja towarzyszących temu procesowi wydarzeń oraz ocena ich przyczyn i skutków podlegały już skrajnie odmiennym interpretacjom i stanowiły tradycyjnie paliwo dla wielu pism antyłacińskich i antygreckich jeszcze $\mathrm{w}$ średniowieczu ${ }^{4}$. Unia kościelna jako oczywiste przeciwieństwo schizmy wydawała się jedynym i logicznym sposobem na przywrócenie jedności chrześcijan, którą zalecił nie kto inny przecież, jak sam Chrystus w Modlitwie Arcykapłańskiej (J 17,11. 20-26). Dlaczego więc ten szczytny, zdawałoby się, cel przywrócenia jedności był tak trudny do osiagnięcia? Dlaczego po raz kolejny w historii część chrześcijan odrzuciła akt unijny, z wszelkimi tego konsekwencjami, traktując ponadto ten gest właśnie jako dzieło obrony własnego „Kościoła prawdziwego”? I wreszcie, dlaczego spór o unię brzeską trwał tak długo? Odpowiedzi nie są wcale łatwe, a przynajmniej nie sposób zawrzeć ich w kilku zdaniach. Choć religijna literatura polemiczna w tym przypadku interesuje mnie głównie jako literaturoznawcę i tekstologa, a zatem patrzę na nią pod kątem migracji tekstów i wątków oraz form wyrazu i strategii podjętych w warstwie komunikacyjnej, to nie sposób zrozumieć rządzących nią mechanizmów w oderwaniu od treści dzieł literackich, zawartych w nich niezliczonych faktów i opinii przytaczanych przez pisarzy, które stanowią dość powtarzalną - jak się okazuje - warstwę, służącą wirtuozerskim popisom hermeneutycznym, sylogistycznym, oratorskim, ale przede wszystkim erudycyjnym. Problem skuteczności (a raczej nieskuteczności) literatury polemicznej moim zda-

${ }^{4}$ Я. Страдомски, Спор „Руси с Русью” о иерковной схизме в религиозной полемике Речи Посполитой XVI-XVII вв., [w:] Религия и русь, XV-XVIII вв., red. А.В. Доронин, Москва, РОССПЭН, 2020, ss. 341-351; zob. też: А. Николов, Между Рим и Константинопол. Из антикатолическата литература в България и славянския православен свят (XI-XVII в.), София, Фондация „Българско историческо наследство”, 2016 (z obfitą literaturą przedmiotu). 
niem dotyczył przede wszystkim odmiennych kanałów komunikacyjnych, jakimi się posługiwano, swoistej polisemantyczności dyskursu, która powodowała, że choć przez dziesięciolecia z rzędu mówiono o tym samym, to jednak każda ze stron pojmowała (i przedstawiała) te same treści w nieco inny albo wręcz zgoła odmienny sposób. W przekazie więc posługiwano się swoistymi kodami kulturowymi, zrozumiałymi jedynie dla przedstawicieli i zwolenników własnego obozu, przez co perswazyjna funkcja polemiki raczej nie przynosiła spodziewanych owoców. W efekcie tego zjawiska do znudzenia można było powtarzać te same treści, przywoływać te same argumenty, choćby zaczerpnięte z najbardziej autorytatywnych źródeł, okraszać je coraz bardziej finezyjnymi uzasadnieniami, podejmować temat zupełnie nieoczekiwanie i bez żadnego związku w kontekstem historycznym (społecznym czy eklezjalnym), w jakim znajdował się aktualnie autor dzieła. Skoro więc ta dyskusja per se była tak często jałowa, to dlaczego podejmowano niemały przecież wysiłek napisania, a następnie wydania kolejnego dzieła, skoro doświadczenie podpowiadało, że nie należy spodziewać się spektakularnych efektów? Odpowiedź na to pytanie stanowi chyba sama natura sporu religijnego, w którym pojawia się imperatyw powinności wiernego (w tym wypadku też autora) i jego bardziej lub mniej formalnego poczucia obowiązku obrony lub apologii spraw fundamentalnych nie tylko dla przyszłej, ale też doczesnej egzystencji człowieka. Jak już wspomniałem, spierano się głównie o Kościół i jego prerogatywy zbawcze, czy zatem mogło być coś bardziej rozpalającego umysły i emocje, niż przekonanie (siebie i kogoś) o przynależności do wspólnoty, która daje wiarygodne nadzieje na zbawienie?

\section{Kościół czy Kościoły?}

Silnie ekskluzywną architekturę Kościoła rzymskokatolickiego, jako jedynej prawdziwej Cerkwi Chrystusowej, poza którą nie ma zbawienia, podsumował w myśli zachodniej i utrwalił sobór trydencki (1545-1563). Na gruncie polskiej literatury religijnej to oficjalne stanowisko pojawiło się już w okresie soborowym, w sporach $\mathrm{z}$ protestantami, natomiast $\mathrm{w}$ literaturze skierowanej w stronę Cerkwi ruskiej obszernie przedstawił je Piotr Skarga w swoim głośnym swego czasu dziele „O jedności Kościoła Bożego pod jednym pasterzem” (Wilno 1577)5. Nakreślony przez Skargę model Kościoła powszechnego oraz jego teologiczno-historyczne uzasadnienie były

${ }^{5}$ P. Skarga, O jedności Kościoła Bożego pod jednym pasterzem, i o greckiem od tej jedności odstapieniu. Z Przestroga i upominanim do narodów ruskich przy Grekach stojacych..., Wilno 1577 (2 wyd. O rzqdzie i jedności Kościoła Bożego..., Kraków 1590, 3 wyd. w ramach Kazań przygodnych, Kraków 1610). Zob. też J. Tretiak, Piotr Skarga w dziejach i literaturze unii brzeskiej, Kraków, Akademia Umiejętności, 1912; R. Łużny, Księdza Piotra Skargi SJ widzenie Wschodu chrześcijańskiego, [w:] PolskaUkraina: 1000 lat sqsiedztwa, t. 2. Studia z dziejów chrześcijaństwa na pograniczu kulturowym i etnicznym, red. S. Stępień, Przemyśl, Południowo-Wschodni Instytut Naukowy, 1994, ss. 69-70. 
obowiązujące dla wszystkich późniejszych przedstawicieli obozu prozachodniego, a więc zarówno rzymskich, jak i greckich katolików. W łacińskiej myśli potrydenckiej Kościół powinien mieć silnie scentralizowaną strukturę feudalno-monarchiczna, cechującą się jedynowładztwem. Istnienie jedynej i najwyższej władzy w Kościele (na wzór władzy cesarskiej) miało warunkować utrzymanie ładu doktrynalnego i spoistości kościelnej, bez których nie jest możliwe kroczenie drogą zbawienia. Konieczność zapewnienia Kościołowi „,najwyższego w rzeczach duchownych pasterza i wodza" nie jest bowiem, jak dowodził ks. Skarga, jakimś czczym ludzkim wymysłem, ale jest nakazem Bożym, któremu podlegają wszyscy chrześcijanie na tym świecie (łącznie z heretykami i schizmatykami!). Demokracja postrzegana była przez jezuite jako pełzające zło, które największe szkody może wyrządzić zwłaszcza w kwestiach dotyczących spraw wiary ${ }^{6}$. W podobnym tonie już ponad dekadę wcześniej wypowiedział się zresztą kardynał Stanisław Hozjusz, w traktacie $O$ jasnym a szczyrym Słowie Bożym (Kraków 1562), gdzie bez ogródek wyjaśniał, że w sprawach wiary „pospólstwo” nie ma prawa głosu. Sam fakt proszenia przez nawet licznych i znamiennych przedstawicieli laikatu nie oznacza jeszcze, że prośba musi zostać wysłuchana, gdyż istnieją sprawy, o których rozstrzyga jedynie Chrystus i jego ziemscy namiestnicy w osobach biskupów rzymskich. Przede wszystkim zaś, jak powiada kardynał Hozjusz, lud nie ma rządzić, ale ma być rządzony, oczywiście przez swych hierarchicznych pasterzy?

W swoistej „monarchii teokratycznej” Kościoła dostrzegano bowiem gwarancję stałości zapewniającej mu przez wieki katolickość (w rozumieniu greckiej ortodoksji), ale przede wszystkim ostoję sprawnego zarządzania, która pozwala zachodniemu chrześcijaństwu ponownie święcić triumfy. Gwarantem ładu, jedności i potęgi Kościoła rzymskiego miał być papież, któremu bezwzględne posłuszeństwo winni wszyscy chrześcijanie, wraz ze swoimi lokalnymi duchowymi pasterzami na czele. Otrząsający się z traumy reformacji Kościół rzymski ekscytował się osiagnięciami misyjnymi w Ameryce i na dalekim Wschodzie, a w sukcesach polityki europejskiej dostrzegał znaki błogosławieństwa Bożego i obecności Jego łaski uświęcającej. Na ortodoksję Zachodu patrzono więc przez pryzmat kondycji Kościoła ziemskiego (wojującego czy też pielgrzymującego), co dawało apologetom tradycji łacińskiej niewątpliwie dobre samopoczucie, ale miało też swój fatalny skutek w recepcji Kościoła greckiego i słowiańskiego, jak również w kształtowaniu myśli soteriologicznej, eklezjalnej i wreszcie unijnej skierowanej do chrześcijan wschodnich. Ale o tym jeszcze za chwilę.

${ }^{6}$ P. Skarga, O jedności Kościoła Bożego..., op.cit., s. 110; zob. Idem, Na treny i lament Theophila Orthologa, do Rusi greckiego nabożeństwa, przestroga..., op.cit., s. 14.

${ }^{7}$ Zob. S. Hozjusz, Księgi o jasnym a szczyrym Słowie Bożym (1558), Kraków 1999, s. 108; zob. P. Skarga, O jedności Kościoła Bożego..., ss. 23-24, 95-56, 110; Idem, Na treny i lament..., op.cit., ss. 14, 46 . 
Promowany przez rzymskokatolickich i unickich pisarzy model Kościoła, oparty głównie na osobie papieża i jurysdykcyjnej podległości mu pozostałych patriarchatów, budziły zdecydowany sprzeciw strony prawosławnej. Kijowski mnich i późniejszy archimandryta Ławry Pieczerskiej, o. Zachariasz Kopysteński, w polemicznym starciu ze Skargą przedstawił własną koncepcję „Rzeczypospolitej ( $\pi$ o $\lambda \imath \tau \varepsilon i ́ \alpha)$ świętej Cerkwi wschodniej”. Obszerna odpowiedź Kopysteńskiego była de facto wyrazem stanowiska prawosławia w kwestii eklezjalnej. „Demokracja” Kościołów wschodnich, oparta na autokefalii i łączności kanonicznej, szła w poprzek lansowanemu przez łacinników modelowi monarchicznemu. Zdaniem o. Zachariasza wspólnota Cerkwi opiera się na jedynowładztwie Chrystusa, jako niewidzialnej, ale realnej Głowy Kościoła, co chroni ten Kościół przed potencjalnie zgubnymi działaniami hierarchów w obszarze ich samowoli czy błędnego nauczania.

\section{Pentarchia}

Kościół wschodni od zawsze wysoko cenił sobie rozsądną autonomię wspólnot lokalnych i bronił suwerenności władzy biskupiej, powołując się na odpowiednie kanony soborowe, które zakazywały biskupom ingerencji w sprawy nienależące do własnych diecezji. Prawosławie nie negowało wyjątkowej pozycji papieża w chrześcijańskiej ekumenie, rozumiejąc ją jednak tylko jako pierwszeństwo honorowe, wynikające $\mathrm{z}$ tradycji i powagi sprawowanego urzędu, a odczytując prymat jedynie w kategorii porządkowej (kolejności patriarchatów), a nie - jak chciał tego Rzym zróżnicowanej jakościowo hierarchii godności biskupiej i rzekomo wynikającej $\mathrm{z}$ tego tytułu zwierzchności prawnej ${ }^{9}$. Protestowano więc przed pomieszaniem dwóch porządków i utożsamieniem autorytetu biskupa rzymskiego w sprawach wiary z jego pozycją w sprawach poza wiarą. Podważano podstawowy argument o boskim czy apostolskim pochodzeniu władzy papieskiej, wskazując na czysto ludzkie - historyczne źródła uprzejmościowego prymatu, wynikające z potrzeby oddania szacunku biskupowi starej cesarskiej stolicy. Honorowe starszeństwo Stolicy Apostolskiej, jak czytamy w tekstach prawosławnych, nigdy nie było uprawnieniem danym raz na zawsze, gdyż wbrew temu, co sądzą łacinnicy, opiera się na wzajemnych relacjach więzi między pięcioma starożytnymi patriarchatami, a te uległy radykalnej zmianie na skutek schizmy kościelnej - schizmy rozumianej przez prawosławny Wschód niezmien-

${ }^{8}$ [Z. Kopysteński], Палінодія или Книга обороны Кафолической Святой Апостолской Всходней Церкви и Святыхъ Патріарховъ, и о Грекохъ, и о Россохъ христіанехъ... (Kijów 1621-1622); pierwodruk [w:] Русская Историческая Библіотека, t. 4: Памятники Полемической Литературы I, red. П. Гилтебрандт, С. Петербургъ 1878, col. 661-662.

${ }^{9}$ Zob. Палінодія или Книга обороныл..., ор.cit., col. 515-528, 626-629. 
nie jako bolesny, ale też konieczny akt odłączenia się od skażonego herezją Kościoła rzymskiego. Takie ujęcie sprawy pozwalało prawosławnej polemice wykluczyć biskupa Starego Rzymu z grona prawowiernych patriarchów i nawet ograniczyć pentarchię do czterech stolic, umieszczając na pierwszym, honorowym miejscu patriarchę Nowego Rzymu - Konstantynopola ${ }^{10}$. Przekonywano, że gdyby o godności i randze patriarchatu stanowić miała jedynie sukcesja apostolska, to najwyższym i najważniejszym z patriarchatów od zawsze powinna być Jerozolima, a ta, jak wiadomo, aż do czasów IV soboru powszechnego (chalcedońskiego) podlegała metropolicie Cezarei. Skoro więc biskup Starego Rzymu otrzymał swoje przywileje z woli ojców soborowych i cesarza (Konstantyna), to mogły one być też nadane lub przeniesione na innego biskupa, jako najwyższego zwierzchnika kościelnego nowej stolicy cesarstwa - Konstantynopola.

\section{Jurysdykcja}

Kwestionowanie aktualnego statusu eklezjalnego Rzymu związane było zjednoczesnym uwypuklaniem wszelkich prerogatyw, jakie na mocy dekretów soborowych otrzymał patriarcha Konstantynopola. Z godna podziwu konsekwencją powoływano się więc na ulubiony argument w tej sprawie, czyli 28. kanon soboru chalcedońskiego, na mocy którego biskup Nowego Rzymu otrzymał zwierzchnią władzę kościelną nad ziemiami Azji, Pontu, Tracji i Barbarii (B $\alpha \beta \alpha \rho \iota \kappa n ́ s)$. Tak sformułowany kanon dawał, w opinii pisarzy ruskich, podstawy do uznania patriarchatu Konstantynopola za jedynego zwierzchnika nowych diecezji misyjnych w Europie północno-wschodniej, w szczególności zaś na bezkresnych połaciach Rusi, a nawet Czech i Polski ${ }^{11}$. Kwestia ustalenia rzeczywistego stanu prawnego na Rusi w sferze cerkiewnej była w Rzeczypospolitej problemem niezwykłej wagi i interesowała wszystkie strony konfliktu, zależał bowiem od tego status prawny bractw i klasztorów stauropigialnych, legalność wyświęcenia biskupów przez działającego w imieniu patriarchatu ekumenicznego patriarchy jerozolimskiego Teofanesa III, rozdawnictwa beneficjów kościelnych przez króla polskiego, czy coraz śmielej wysuwane pretensje nowo utworzonego (1589) patriarchatu moskiewskiego do zwierzchnictwa nad prawosławiem polsko-litewskim.

Rozważaniom na ten temat, łącznie z niezwykle rozbudowanym wątkiem chrystianizacji Rusi, i to nawet pięciokrotnej (!), towarzyszyła zwykle dość ciekawa greckokatolicka perspektywa eklezjologiczna. W opinii unitów trwająca już formalnie niemal sześć wieków schizma Kościoła dawała podstawy do zanegowania jakichkolwiek praw zwierzchności patriarchatu Konstantynopola do terenów Rusi, które

\footnotetext{
${ }^{10}$ Ibidem, col. 520.

${ }^{11}$ Zob. J. Stradomski, Spory o ,wiare grecka”..., ss. 91-94, passim.
} 
to miały obowiązywać jedynie w warunkach utrzymania łączności kanonicznej ze Stolicą Apostolską. Aksjomatyczne uznanie praw zwierzchności biskupa rzymskiego nad całym Kościołem powszechnym pozwalało unitom z dużą swobodą kreślić obraz Cerkwi kijowskiej ochrzczonej wprawdzie przez Greków, ale od początku uznającej zwierzchnictwo papieskie. Kontakty z Kościołem rzymskim metropolitów kijowskich, takich jak Grzegorz Cambłak, Izydor, Grzegorz Bułgar, Mizael Pstrucki i kilku innych biskupów, jednoznacznie uznawano za dowód odporności prawosławia ruskiego na grecką schizmę i utrzymywania zalążków jedności kościelnej na długo przed podjęciem aktywności unijnej na linii Konstantynopol - Rzym ${ }^{12}$. Unia na Rusi (niezależnie od tego, czy florencka, czy brzeska) stanowić więc miała nie tyle zupełnie nową jakość eklezjalną, co zakrojoną na szeroką skalę restytucję stanu pierwotnej jedności Kościoła powszechnego, którego stery od czasów apostolskich znajdowały się, rzecz jasna, w Rzymie. Zgodnie z tą myślą Cerkiew ruska uniknęła tragicznych skutków odłączenia się odstępnych Greków od Kościoła zachodniego, które z całą oczywistością widoczne są na Bałkanach.

\section{Schizma kościelna}

Dla propagatorów idei chrześcijaństwa pod papieskim pastorałem było sprawą oczywistą, że upadek Cesarstwa bizantyńskiego i późniejsza niewola islamska, w jaką wpadli prawosławni Grecy i Słowianie na Bałkanach, były - z dopustu Bożego jawną karą za „rozerwanie jedności Kościoła”. Obarczenie patriarchów Konstantynopola - Focjusza i Cerulariusza - winą za schizmę kościelną było stałym i obszernie omawianym wątkiem piśmiennictwa polemiczno-religijnego i historycznego w XVI, XVII a nawet na początku XVIII wieku. Z niebywałą szczegółowością opisywano wydarzenia, które doprowadziły - zdaniem rzymskich i greckich katolików - do katastrofy świata greckiego i stały się początkiem nieszczęść, jakie nieuchronnie spadły z woli Bożej na schizmatyków, dotykając ich państwo w sferze politycznej, duchowej, socjalnej i społecznej ${ }^{13}$. Upadek Bizancjum i całego chrześcijańskiego Wschodu pod nawałą islamu miał być ostatecznym znakiem gniewu Bożego i urze-

${ }^{12}$ R. Łużny, Adama Hipacego Pocieja „Parenetica”. Z nowych odczytań najdawniejszej ruskiej literatury religijno-polemicznej, [w:] Unia brzeska: geneza, dzieje i konsekwencje w kulturze narodów słowiańskich, red. R. Łużny, F. Ziejka, A. Kępiński, Kraków, Wydawnictwo Universitas, 1994, ss. 346348; В. Зема, Між апокрифом та історією (Флорентійська унія в православній полеміиі), [w:] А се єго сребро. Збірник праџь на пошану члена-кореспондента НАН Украӥни Миколи Федоровича Котляра з нагоди 70-річчя, Київ, Інститут історії України НАН України, 2002, ss. 207-224; Idem, Флорентійська унія та автокефалія Церкви, „Український історичний журнал” 2003, nr 1, ss. 53-67.

${ }^{13}$ Szerzej na ten temat: J. Stradomski, Spory o „, wiare grecka”..., op.cit., ss. 143-271; Я. Страдомски, Спор “Руси с Русью”..., op.cit., ss. 347-351. 
czywistnieniem Jego zamysłu, aby wiara szerzyła się odtąd już tylko na Zachodzie i wśród pogan (głównie Słowian i Węgrów, a takoż ludów Ameryk, Indii i Japonii), którzy wkrótce mieli zastąpić schizmatyckich Greków (i Serbów!) dla eklezjalnej równowagi. W potrydenckiej literaturze religijnej znajdziemy całe rozdziały traktujące o tym, jak należy rozpoznawać prawdziwy Kościół Boży i dlaczego z pewnością nie jest nim już Kościół grecki ${ }^{14}$. W oderwaniu się chrześcijańskiego Wschodu od Kościoła rzymskiego i oporze przed przyjęciem unii upatrywano głównej przyczyny utraty łaski uświęcającej, pozyskiwania nowych świętych (a nawet utrzymania relikwii tych starych!), utraty nauk, wszech panoszącej się symonii, upadku obyczajów i zdolności Cerkwi greckiej do nawracania nowych narodów.

Żonglowanie ideami tzw. „Kościoła płodnego” i „Kościoła niepłodnego”, zawężone jeszcze do konkretnych obszarów geograficznych, dawało koryfeuszom Kościoła rzymskiego pozory oczywistości przytaczanych przez nich argumentów i jednoznaczności wyciąganych wniosków ${ }^{15}$. Katolicko-unicka ofensywa promująca teologiczne, dyscyplinarne i intelektualne osiagnięcia Zachodu miała przekonać „zacofaną Ruś", że jedynie zjednoczenie z Rzymem daje nadzieję na odrodzenie dawnego splendoru Cerkwi, a przede wszystkim udział w środkach zbawczych Kościoła powszechnego. Wszystkie wątki polemiki zaczynają znów zbiegać się u źródła, którym jest spór o rolę biskupa rzymskiego (szerzej Kościoła rzymskiego) w strukturze Kościoła powszechnego i jego prerogatywy w obszarze dogmatyki oraz jurysdykcji. Bo uznanie zwierzchności papieskiej we wszystkich aktach unijnych było warunkiem brzegowym, nie podlegało negocjacjom, w odróżnieniu od spraw dyscyplinarnych, liturgicznych, a nawet teologicznych.

\section{Trudne drogi powrotu do jedności}

Cerkiew prawosławna na te same wydarzenia z przeszłości patrzyła oczywiście z zupełnie innej strony i miała całkiem odmienne interpretacje przedstawianych faktów. Kontrreformacyjny model Kościoła powszechnego, silnie scentralizowanego

${ }^{14} \mathrm{Z}$ wielu pism na ten temat warto wskazać choćby obszerny traktat Teofila Rutki zatytułowany Herby abo Znaki Kościoła prawdziwego Katolikom dla pociechy duchowej... (Lublin 1696), który podsumowuje potrydenckie stanowisko Kościoła rzymskokatolickiego w kwestii ekskluzywizmu eklezjalnego i soteriologicznego oraz odnosi się do stosowanej zwykle w tym przypadku argumentacji.

${ }^{15}$ Zob. A. Naumow, Prawosławni święci I Rzeczypospolitej, [w:] Święci w kulturze i duchowości dawnej $i$ współczesnej Europy, red. W. Stępniak-Minczewa, Z.J. Kijas, Kraków, Wydawnictwo Naukowe PAT, 1999, ss. 21-30; Idem, Święci lokalni w myśli kijowskiej pierwszej połowy XVII wieku, [w:] Ars graeca - Ars latina. Studia dedykowane Prof. A. Różyckiej-Bryzek, Kraków, Wydawnictwo UJ, 2001, ss. 199-206; Idem, Święty Mikołaj w Bari jako argument w polemice wyznaniowej, [w:] Instaurare omnia in Christo. O zbawieniu, teologii, dialogu i nadziei. Profesorowi Wactawowi Hryniewiczowi OMI w 70. rocznice urodzin, red. P. Kantyka, Lublin, Wydawnictwo KUL, 2006, ss. 577-589. 
i wręcz monarchicznego, budził zdecydowany opór chrześcijańskiego Wschodu. W propozycjach zjednoczeniowych prawosławie oczekiwało raczej powrotu do stanu starożytnej, pierwotnej równowagi, bez dominacji któregoś z kościołów, bez konieczności odcinania się od korzeni własnej wiary i tradycji, oczekiwało kościelnego zjednoczenia, ale z zachowaniem rozsądnej autonomii, powrotu do jedności, ale „bez zmieszania".

Wspomniany już o. Zachariasz Kopysteński tak oto wyraża stanowisko Kościoła wschodniego w tej kwestii:

„A gdy [papież - J.S.] poprzestanie na wszystkich pierwotnych prawach cerkiewnych, zrzeknie się nowinek a całą pierwotną starożytność Cerkwi zachodniej przywróci, i wiarę wspólnie z patriarchami wyznawać [będzie], do społeczności swojej go przyjmą i do dawnych prerogatyw go przypuszczą. Do czego i wszystkie inne chrześcijańskie sekty, z tegoż Kościoła rzymskiego wyległe, jak rozumiemy, z ochotą przystąpią i za łaską Bożą stanie się nie unia, ale unitas, nie zjednoczenie, ale jedność!’16

Kluczem do płaszczyzny porozumienia obu Kościołów, jak widać, w mniejszym stopniu zdawały się być spory teologiczne, niezgodności liturgiczne czy obrzędowe, aniżeli kontrowersyjne poczynania biskupów rzymskich, których obarczano winą za utrzymującą się schizmę i pogwałcenie starożytnych zasad. Na Wschodzie zdawano sobie jednak sprawę z niemożności powrotu do stanu sprzed ponad tysiąclecia, wobec czego proponowany model chrześcijaństwa starożytnego miał być jedynie punktem wyjścia dla wypracowania projektu nowego porozumienia, bowiem przedstawiane dotychczas przez Rzym i jego popleczników podstawy unii były nie do przyjęcia. Zresztą sami katolicy i unici dostarczali prawosławnym argumentów świadczących o tym, że w eklezjologii zachodniej papież jest zwornikiem wszystkich spraw dotyczących hierarchii, liturgiki, sakramentologii, a nawet soteriologii. Wymownym tego przykładem jest wspomniane już dzieło Piotra Skargi „O jedności Kościoła Bożego...”, w którym bezkompromisowy jezuita zarzuca prawosławnym Rusinom, że prócz kwestionowania przez nich pozycji papieża w Kościele i trwania w schizmie, na przeszkodzie do zbawienia stoją im też między innymi używanie języka słowiańskiego w liturgii, odprawianie eucharystii na kwaśnym chlebie czy małżeństwo duchownych parafialnych. Zarzuty te padają w 1577 roku (a nawet jeszcze w późniejszym przedruku z 1590 roku), natomiast zawarta zaledwie kilka lat później unia brzeska z wszystkich nich pozostawiła w mocy zaledwie jeden, czyli konieczność uznania papieża za jedynego arcypasterza i widzialną głowę Kościoła

${ }^{16}$ Палінодія или Книга обороны..., col. 718; zob. Ibidem, col. 1117. Przekład i podkreślenia moje - J.S. 
powszechnego ${ }^{17}$. To wystarczyło, by w oczach katolików niektórzy prawosławni dotychczasowi schizmatycy, nazywani zresztą niekiedy równie pogardliwie heretykami albo „turkogrecją, a dziś już podlegli Stolicy Apostolskiej grekokatolicy, znaleźli się w przestrzeni „Kościoła prawdziwego” i w pełni mogli dostąpić obietnicy zbawienia wiecznego. Nawet z perspektywy Rzymu unia miała więc swoją cenę, choć ustępstwa traktowano zapewne jako doraźną konieczność dla osiagnięcia wyższych celów i w nadziei na stopniowe wycofywanie się z nich. Tak zresztą się stało, bowiem znacznie mniejszy niż się spodziewano entuzjazm dla unii w Rzeczypospolitej sprawił, że rzymskokatolickie duchowieństwo patrzyło ze zniechęceniem i rosnącą nieufnością na grekokatolików, z czasem coraz bardziej otwarcie sugerując im, że dla pewności zbawienia powinni przejść na katolicyzm. Można podać przykłady. Dwukrotny konwertyta, z prawosławia na unię i z unii na katolicyzm, Kasjan Kalikst Sakowicz poświęcił cały traktat na wykazywanie rzekomych błędów we wschodniochrześcijańskiej liturgii prawosławnej (a zatem i unickiej), które jego zdaniem czynią wattpliwymi sakramenty i stoją na przeszkodzie zbawieniu, dlatego lepiej od razu przejść na obrządek rzymski ${ }^{18}$. Natomiast kaznodzieja króla Władysława IV i hagiograf arcybiskupa Jozafata Kuncewicza, dominikanin Fabian Birkowski, poszedł jeszcze dalej, gdy dowodził, że bez łączności z Rzymem nie jest możliwe nawet męczeństwo za wiarę, które staje się w takiej sytuacji zaledwie „materialne”, ale nie „formalne”! W połajankach na heretyków i schizmatyków krewki kaznodzieja zakrzykuje: „O jako szkaradny grzech jest odszczepieństwa, który ani ze krwią męczeńską wcisnąć się do nieba nie może!"19. Jak widzimy, bez przypadnięcia do tronu Piotrowego, wschodniemu chrześcijaninowi nawet śmierć za Chrystusa na nic się zdać nie mogła.

\section{Cena zjednoczenia}

Zdecydowany opór, jaki wywołała unia 1596 roku w kręgach Kościoła ruskiego, nie był jedynie przejawem partykularyzmu i złej woli hierarchów cerkiewnych,

${ }^{17}$ Zob. A. Naumow, Język - deklaracja przynależności czy narzędzie? Z dylematów I Rzeczypospolitej, [w:] VIII Kolokwium Slawistyczne Polsko-Butgarskie, red. M. Walczak-Mikołajczakowa, Gniezno, Gnieźnieńska Firma Wydawnicza „TUM”, 2001, ss. 21-34.

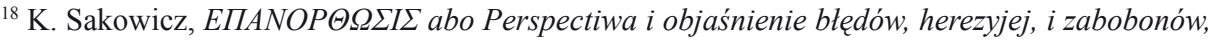
$w$ grekoruskiej Cerkwi disunitskiej tak $w$ artykułach wiary, jako w administrowaniu sakramentów, $i$ w inszych obrzqdkach i ceremoniach znajdujacych się..., Kraków 1642. Dzieło wzbudziło wielkie kontrowersje i doczekało się surowej odpowiedzi zarówno ze strony prawosławnych (Euzebi Pimin [P. Mohyła], $\Lambda I \Theta O \Sigma$ abo kamień z procy prawdy Cerkwie świętej prawosławnej ruskiej. Na skruszenie fałecznociemnej Perspektiwy albo raczej paszkwilu od Kassiana Sakowicza..., Kijów 1644), jak i unitów, których nieuchronnie również atakowało (P. Woyna-Orański, Zwierciadło albo zasłona ... naprzeciw uszczypliwej Perspektywie ks. Kassiana Sakowicza..., Wilno 1645).

${ }^{19} \mathrm{~F}$. Birkowski, Exorbitancye ruskie z Grekow odszczepieńcow, heretyckie z konfederatow. Kazania dwoie..., Kraków 1633, s. 13. 
jak twierdzili ich współcześni adwersarze, ale wynikał z autentycznej obawy przed utratą tożsamości prawosławia. Również unickim hierarchom w większości przypadków także nie należy odmawiać szlachetnych pobudek skłaniających ich do ustępstw wobec Rzymu, które wydawały się wówczas konieczną ceną ratowania podupadającej Cerkwi ruskiej. W środowisku tym żywiono nadzieję, że unia będzie udanym początkiem upragnionego zjednoczenia Kościoła powszechnego oraz przy okazji przyniesie odnowę odnowę życia duchowego, dyscypliny i kultury cerkiewnej.

Trudna sytuacja prawosławia w Rzeczypospolitej po proklamacji unii z czasem wymogła również na działaczach cerkiewnych przyjęcie bardziej elastycznego stanowiska $\mathrm{w}$ relacjach z katolikami. Wyrazem takich dążeń był chociażby - oficjalnie anonimowy - memoriał unijny Piotra Mohyły z 1644 roku skierowany do papieża Urbana VIII. Metropolita kijowski poddał w nim krytyce zasady i formę realizacji unii brzeskiej, przedstawiając jednocześnie własny projekt „unii bez zniszczenia”, powrotu do „świętych zasad”, do „źródła i początku rzeczy”, co pozwoliłoby uniknąć powtórek bolesnych lekcji z przeszłości ${ }^{20}$. W myśl tej propozycji realne zjednoczenie Kościoła ruskiego z Rzymem byłoby możliwe bez konieczności przekształcania jednego wyznania w drugie i odcinania się Cerkwi prawosławnej od patriarchatu Konstantynopola, a co za tym idzie, od całego chrześcijańskiego Wschodu. Kompromisowym rozwiązaniem i alternatywą dla prawosławnych Słowian wydawało się powołanie odrębnego patriarchatu w Kijowie, jednak pomysł ten nie znalazł uznania ani w Konstantynopolu, ani w Rzymie ${ }^{21}$. Kościół łaciński tradycyjnie podchodził do problemu z pozycji siły, a prawosławie ruskie, ciążące od połowy XVII wieku coraz bardziej ku Moskwie, skłaniało się raczej w stronę swojego dawnego, konserwatywnego stanowiska ${ }^{22}$. Dla owocnego dialogu potrzeba było bowiem bezinteresowności i zrozumienia obu stron, a koncepcje zjednoczenia przez unię w tym przypadku - jak pokazuje literatura i historia - były zgoła odmienne.

Arcybiskup połocki Melecjusz Smotrycki w jednym ze swych dzieł przedstawił taką oto, utopijnie brzmiącą wizję Kościoła powszechnego z jego pięcioma najważniejszymi patriarchami:

${ }^{20}$ Zob. W. Hryniewicz, Przeszłość zostawić Bogu. Unia i uniatyzm w perspektywie ekumenicznej, Opole, Wydawnictwo Świętego Krzyża, 1995, ss. 81-96; R. Łużny, Metropolita Piotr Mohyła - człowiek na pograniczu kulturowym grecko-stowiańskim i łacińsko-polskim, [w:] Acta Polono-Ruthenica I, red. A. Bartoszewicz, Olsztyn, Uniwersytet Warmińsko-Mazurski w Olsztynie, 1996, ss. 333-348.

${ }^{21}$ Zob. Andrusiak M., Sprawa Patriarchatu Kijowskiego za Władysława IV, [w:] Prace historyczne w 30-lecie działalności profesorskiej S. Zakrzewskiego, Lwów, Nakładem Komitetu byłych uczni z zasiłkiem Ministerstwa W.R.i.O.P, 1934, ss. 271-285; A. Mironowicz, Piotr Mohyła a idea unii kościelnej, ,Studia Podlaskie” XI, Białystok 2001, ss. 25-34.

${ }^{22}$ T. Hodana, Między królem a carem. Moskwa w oczach prawosławnych Rusinów - obywateli Rzeczypospolitej, Kraków, Wydawnictwo „Scriptum”, 2008, passim. 
„O zdarzyłby to Pan Bóg, aby te pięć ciała Pana Chrystusowego zmysły: pięć, mówiemy, świętej Cerkwie Bożej Katolickiej Pasterze, przedniejszych Apostolskich Stolic Biskupowie, Rzymski, Konstantynopolski, Alexandryiski, Antiochenski, i Hierosolimski, tak przystojnie, [...] chodzili w powołaniu tym, w którym są powołani [...] aby zachowali jedność Ducha w związce pokoju. Aby nie mówiło oko słuchowi, nie jesteś z ciała, zaczym nie jesteś potrzebne: a słuch powonieniu, ni powonienie smakowaniu, ni smakowanie dotykaniu. Bo jeśliby wszystko ciało było okiem, gdzieżby był słuch? gdzieby też wszystko było słuchem, gdzież powonienie? gdyby wszystko było powonieniem, gdzie smakowanie? gdzie na koniec i dotykanie, gdyby wszystko ciało było smakowaniem? Ale teraz rozłożył Bóg zmysły te, każdy z nich w ciele jako chciał. Co gdyby wszytkie były jednym zmysłem, gdzież ciało? A tak teraz pięć zmysłów, ale jedno ciało. Nic jeden zmysł bez inszych, nic i miasto wszystkich, boby tak nie było ciała"'23.

Wypowiedź Smotryckiego najlepiej ukazuje, jak bezzasadne i szkodliwe było doszukiwanie się aksjologicznej hierarchii patriarchatów, nieustanne dowodzenie, kto spowodował schizmę, i kto się od kogo odłączył, a przede wszystkim traktowanie unii jako aktu ekspiacyjnego. Sprowadzanie kontrowersji wokół unii brzeskiej do kilku spraw dogmatycznych i dyscyplinarnych było i jest oczywistym uproszczeniem.

Synod zamojski z 1720 roku stanowi symboliczną klamrę zamykającą okres polemiki wokół unii brzeskiej. Na synodzie tym podjęto radykalne kroki w kierunku latynizacji Cerkwi unickiej i ścisłego włączenia jej w struktury Kościoła rzymskiego $^{24}$. Spełnił się w ten sposób czarny scenariusz i przestrogi sprzed ponad stulecia, w których ostrzegano, że fundamenty unii są złe i nieuchronnie prowadzą do korekt doktryny oraz marginalizacji Cerkwi, i to również tej greckokatolickiej. Na cofnięcie podjętych przed laty decyzji było już wtedy jednak za późno.

${ }^{23}$ M. Smotrycki, Verificatia Niewinności: y omylnych po wszytkiey Litwie y Bialey Rusi rozsianych... Nowin... Vprzatnienie..., Wilno 1620 (dwie ed.), s. 63v.; reprint [w:] Collected Works of Meletij Smotryc 'kyj, with an Introduction by David A. Frick, Cambridge 1987 (Harvard Library of Early Ukrainian Literature. Texts, vol. 1), s. 338.

${ }^{24} \mathrm{~W}$ Zamościu odbyły się trzy zasadnicze sesje synodu w dniach 26 sierpnia, 1 oraz 17 września. Literatura poświęcona synodowi jest obszerna i zróżnicowana pod względem wnikliwości ocen, stopnia wykorzystania źródel, znajomości kontekstów i realiów epoki, a wreszcie obiektywizmu. Przegląd publikacji w pracach monograficznych, zob. nр.: Ю. Федорів, Замойський синод 1720 р., Рим 1972, ss. 14-20; P. Nowakowski, Problematyka liturgiczna w międzywyznaniowej polemice po unii brzeskiej (1596-1720), Kraków, Wydawnictwo Naukowe PAT, 2004; W. Bobryk, Duchowieństwo unickiej diecezji chetmskiej w XVIII wieku, Lublin, Towarzystwo Instytutu Europy Środkowo-Wschodniej, 2005; D. Ciołka, Latynizacja Kościoła unickiego w Rzeczypospolitej po synodzie zamojskim, Białystok, Libra Wydawnictwo i Drukarnia, 2014 i najnowsza praca na ten temat: Dziedzictwo Synodu Zamojskiego 1720-2020. Wyzwania i perspektywy, red. P. Nowakowski, Kraków, Wydawnictwo Avalon 2021. 


\section{Literatura}

Źródła

Birkowski Fabian, Exorbitancye ruskie z Grekow odszczepieńcow, heretyckie z konfederatow. Kazania dwoie..., Kraków 1633.

Hozjusz Stanisław, Księgi o jasnym a szczyrym Słowie Bożym, Kraków 1558 (2 wyd., Kraków 1999).

[Kopysteński Zachariasz], Палінодія или Книга обороны Кафолической Святой Апостолской Всходней Церкви и Святыхъ Патріарховъ, и о Грекохъ, и о Россохъхристіанехъ... (Kijów 1621-1622); pierwodrukw:Русская Историческая Библіотека t. 4: Памятники Полемической Литературы I, red. П. Гилтебрандт, С. Петербургъ 1878, col. 313-1200.

Pimin Euzebi [P. Mohyła], $\Lambda I \Theta O \Sigma$ abo kamień z procy prawdy Cerkwie świętej prawostawnej ruskiej. Na skruszenie fatecznociemnej Perspektiwy albo raczej paszkwilu od Kassiana Sakowicza..., Kijów 1644.

Rutka Teofil, Herby abo Znaki Kościoła prawdziwego Katolikom dla pociechy duchowej..., Lublin 1696.

Sakowicz Kassian, EПANOP $\Theta \Omega \Sigma I \Sigma$ abo Perspectiwa i objaśnienie błędów, herezyjej, i zabobonów, $w$ grekoruskiej Cerkwi disunitskiej tak $w$ artykułach wiary, jako $w$ administrowaniu sakramentów, $i w$ inszych obrzadkach $i$ ceremoniach znajdujacych się..., Kraków 1642.

Skarga Piotr, Na treny i lament Theophila Orthologa, do Rusi greckiego nabożeństwa, przestroga ..., Kraków 1610.

Skarga Piotr, O jedności Kościoła Bożego pod jednym pasterzem, i o greckiem od tej jedności odstapieniu. Z Przestroga $i$ upominanim do narodów ruskich przy Grekach stojacych..., Wilno 1577 (2 wyd. O rzadzie i jedności Kościoła Bożego..., Kraków 1590, 3 wyd. w ramach Kazań przygodnych, Kraków 1610).

Smotrycki Melecjusz, Verificatia Niewinności: y omylnych po wszytkiey Litwie y Bialey Rusi rozsianych ... Nowin ... Vprzatnienie..., Wilno 1620 (dwa wyd.); reprint [w:] Collected Works of Meletij Smotryc 'kyj, with an Introduction by David A. Frick, Cambridge 1987 (Harvard Library of Early Ukrainian Literature. Texts, vol. 1).

Woyna-Orański Pachomiusz, Zwierciadło albo zastona... naprzeciw uszczypliwej Perspektywie ks. Kassiana Sakowicza..., Wilno 1645.

Opracowania

Andrusiak M., Sprawa Patriarchatu Kijowskiego za Władystawa IV, [w:] Prace historyczne w 30-lecie działalności profesorskiej S. Zakrzewskiego, Lwów, 
Nakładem Komitetu byłych uczni z zasiłkiem Ministerstwa W.R.i.O.P, 1934, ss. $271-285$

Bobryk W., Duchowieństwo unickiej diecezji chetmskiej w XVIII wieku, Lublin, Towarzystwo Instytutu Europy Środkowo-Wschodniej, 2005, 217 ss.

Ciołka D., Latynizacja Kościoła unickiego w Rzeczypospolitej po synodzie zamojskim, Białystok, Libra Wydawnictwo i Drukarnia, 2014, 320 ss.

Czupryk R., Unia brzeska: dzieło kościelnej jedności: retrospekcja historyczna, Sandomierz, Rzeszów: Rafał Czupryk, 2015, 153 ss.

Dziedzictwo Synodu Zamojskiego 1720-2020. Wyzwania i perspektywy, red. P. Nowakowski, Kraków, Wydawnictwo Avalon, 2021, 352 ss.

Dziedzictwo unii brzeskiej, red. R. Dobrowolski, M. Zemło, Lublin, Supraśl, Wydawnictwo KUL, Collegium Suprasliense, 2012, ss. 424.

Gudziak B. A., Kryzys i reforma. Metropolia kijowska, patriarchat Konstantynopola i geneza unii brzeskiej, przeł. H. Leskiw, A. Chrin, Lublin, Wydawnictwo Uniwersytetu Marii Curie-Skłodowskiej, 2008 (ang. wydanie: Cambridge (Mass.) 1998), 512 ss.

Hodana T., Między królem a carem. Moskwa w oczach prawosławnych Rusinów obywateli Rzeczypospolitej, Kraków, Wydawnictwo „Scriptum”, 2008, 262 ss.

Hryniewicz W., Przeszłość zostawić Bogu. Unia i uniatyzm w perspektywie ekumenicznej, Opole, Wydawnictwo Świętego Krzyża, 1995, 174 ss.

Łużny R., Adama Hipacego Pocieja „Parenetica”. Z nowych odczytań najdawniejszej ruskiej literatury religijno-polemicznej, [w:] Unia brzeska: geneza, dzieje i konsekwencje w kulturze narodów słowiańskich, pod red. R. Łużnego, F. Ziejki i A. Kępińskiego, Kraków, Wydawnictwo Universitas, 1994, ss. 346348.

Łużny R., Księdza Piotra Skargi SJ widzenie Wschodu chrześcijańskiego, [w:] Polska-Ukraina: 1000 lat sqsiedztwa, t. 2. Studia z dziejów chrześcijaństwa na pograniczu kulturowym i etnicznym, red. S. Stępień, Przemyśl, Południowo-Wschodni Instytut Naukowy Przemyśl, 1994, ss. 69-75.

Łużny R., Metropolita Piotr Mohyła - czlowiek na pograniczu kulturowym greckostowiańskim i tacińsko-polskim, [w:] Acta Polono-Ruthenica I, red. A. Bartoszewicz, Olsztyn, Uniwersytet Warmińsko-Mazurski w Olsztynie, 1996, s. 333348 .

Mironowicz A., Piotr Mohyła a idea unii kościelnej, „Studia Podlaskie” XI, Białystok 2001, ss. 25-34.

Mironowicz A., Podlaskie ośrodki i organizacje prawosławne w XVI i XVII wieku, Białystok, Dział Wydawnictw Filii UW, 1991, 301 ss.

Mironowicz A., Prawostawie $i$ unia za panowania Jana Kazimierza, Białystok, Orthdruk, 1997, 322 ss. 
Moskałyk J., Problem zjednoczenia w Kościele kijowskim w I połowie XVII wieku, Poznań, Uniwersytet Adama Mickiewicza. Wydział Teologiczny. Redakcja Wydawnictw, 2006, 225 ss.

Naumow A., Święci lokalni w myśli kijowskiej pierwszej połowy XVII wieku, [w:] Ars graeca-Ars latina. Studia dedykowane Prof. A. Różyckiej-Bryzek, Kraków, Wydawnictwo UJ, 2001, ss. 199-206.

Naumow A., Domus divisa. Studia nad literaturq ruskq w I Rzeczypospolitej, Kraków, „Collegium Columbinum”, 2002, 399 ss.

Naumow A., Język-deklaracja przynależności czy narzędzie? Z dylematów I Rzeczypospolitej, [w:] VIII Kolokwium Slawistyczne Polsko-Butgarskie, red. M. Walczak-Mikołajczakowa, Gniezno, Gnieźnieńska Firma Wydawnicza „TUM”, 2001, ss. 21-34.

Naumow A., Prawosławni święci I Rzeczypospolitej, [w:] Święci w kulturze i duchowości dawnej i wspótczesnej Europy, red. W. Stępniak-Minczewa, Z. J. Kijas, Kraków, Wydawnictwo Naukowe PAT, 1999, ss. 21-30.

Naumow A., Święty Mikołaj w Bari jako argument w polemice wyznaniowej, [w:] Instaurare omnia in Christo. Ozbawieniu, teologii, dialoguinadziei. Profesorowi Wacławowi Hryniewiczowi OMI w 70. rocznice urodzin, red. P. Kantyka, Lublin, Wydawnictwo KUL, 2006, ss. 577-589.

Naumow A., Święci Cyryl i Metody w polemice wyznaniowej, [w:] Środkowoeuropejskie dziedzictwo cyrylo-metodiańskie. Międzynarodowa konferencja naukowa, red. A. Barciak, Katowice, Societas Scientiis Silesiae Superioris - Instytut Górnośląski, 1999, ss. 173-184.

Nowakowski P., Problematyka liturgiczna w międzywyznaniowej polemice po unii brzeskiej (1596-1720), Kraków, Wydawnictwo Naukowe PAT, 2004, ss. 304.

Stradomski J., Spór o historię i wartości w świetle katolicko-unicko-prawosławnej polemiki religijnej w Pierwszej Rzeczypospolitej (koniec XVI - poczatek XVIII wieku), [w:] Między Wschodem a Zachodem. Prawostawie i unia, red. M. Kuczyńska, Warszawa, Wydawnictwa Uniwersytetu Warszawskiego, 2017, ss. 238276.

Stradomski J., Spory o „, wiarę greckq” w dawnej Rzeczypospolitej, Kraków, Wydawnictwo „Scriptum”, 2003, 341 ss.

Tretiak J., Piotr Skarga $w$ dziejach i literaturze unii brzeskiej, Kraków, Akademia Umiejętności, 1912, 352 ss.

Unia brzeska: geneza, dzieje i konsekwencje w kulturze narodów stowiańskich, pod red. R. Łużnego, F. Ziejki i A. Kępińskiego, Kraków, Wydawnictwo Universitas, 1994, 555 ss.

Unia brzeska i jej konsekwencje. W 420 rocznice synodu unijnego, red. A. Krochmal, A. Nowak, Przemyśl, Archiwum Państwowe 2017, 353 ss. 
Unia brzeska: wybór źródet, wyboru tekstów dokonał M. Melnyk, tłum. i oprac. M. Melnyk, W. Pilipowicz, Olsztyn, Katedra Aksjologicznych Podstaw Edukacji.

Wydział Nauk Społecznych. Uniwersytet Warmińsko-Mazurski, 2016, 140 ss.

Дмитриев М.В., Между Римом и Царьградом. Генезис Брестской иерковной унии 1595-1596 г2., Москва, Издательство Московского Государственного Университета, 2003, $320 \mathrm{ss}$.

Зема В., Між апокрифом та історією (Флорентійська унія в православній полеміці), [w:] А се єго сребро. Збірник пращь на пошану члена-кореспондента НАН Украӥни Миколи Федоровича Котляра з нагоди 70-річчя, Київ, Інститут історії України НАН України, 2002, ss. 207-224.

Зема В., Флорентійська унія та автокефалія Церкви, „Український історичний журнал" 2003, nr 1, ss. 53-67.

Николов А., Между Рим и Константинопол. Из антикатолическата литература в България и славянския православен свят (XI-XVII в.), София, Фондация "Българско историческо наследство”, 2016, 353 ss.

Страдомски Я., Спор „Руси с Русью” о иерковной схизме в религиозной полемике Речи Посполитой XVI-XVII вв., [w:] Религия и Русь, XV-XVIII вв., red. А.В. Доронин, Москва, РОССПЭН, 2020, ss. 341-351.

Тимошенко Л., Берестейська унія 1596 р., Дрогобич, Дрогобицький державний педагогічний університет ім. I. Франка, 2004, 197 ss.

Федорів Ю., Замойський синод 1720 р., Рим, (Видання „Богословії”), 1972; to samo: „Богословія” 35 (1971), ss. 5-71.

\section{References}

Primary sources

Birkowski Fabian, Exorbitancye ruskie z Grekow odszczepieńcow, heretyckie z konfederatow. Kazania dwoie..., Kraków 1633.

Hozjusz Stanisław, Księgi o jasnym a szczyrym Słowie Bożym, Kraków 1558 (ed. 2, Kraków 1999).

[Kopysteński Zachariasz], Палінодія или Книга оборонь Кафолической Святой Апостолской Всходней Церкви и Святыхъ Патріарховъ, и о Грекохъ, и о Россохъ христіанехъ... (Kiev 1621-1622); first print in: Русская Историческая Библіотека, vol. 4: Памятники Полемической Литературы I, П. Гилтебрандт (Ed.), St. Petersburg, 1878, col. 313-1200.

Pimin Euzebi [P. Mohyła], $\Lambda \mathrm{I} O \mathrm{O}$ abo kamień z procy prawdy Cerkwie świętej prawosławnej ruskiej. Na skruszenie fałecznociemnej Perspektiwy albo raczej paszkwilu od Kassiana Sakowicza..., Kiev 1644. 
Rutka Teofil, Herby abo Znaki Kościoła prawdziwego Katolikom dla pociechy duchowej..., Lublin 1696.

Sakowicz Kassian, EПANOP $\Theta \Omega \Sigma I \Sigma$ abo Perspectiwa i objaśnienie błędów, herezyjej, $i$ zabobonów, $w$ grekoruskiej Cerkwi disunitskiej tak $w$ artykułach wiary, jako $w$ administrowaniu sakramentów, $i$ w inszych obrzqdkach $i$ ceremoniach znajdujacych się..., Kraków 1642.

Skarga Piotr, Na treny i lament Theophila Orthologa, do Rusi greckiego nabożeństwa, przestroga..., Kraków 1610.

Skarga Piotr, Ojedności Kościoła Bożego pod jednym pasterzem, i o greckiem od tej jedności odstapieniu. Z Przestroga $i$ upominanim do narodów ruskich przy Grekach stojacych..., Vilnius 1577 (ed. 2 O rzqdzie ijedności Kościoła Bożego..., Kraków 1590, ed. 3 included in Kazania przygodne, Kraków 1610).

Smotrycki Melecjusz, Verificatia Niewinności: y omylnych po wszytkiey Litwie y Bialey Rusi rozsianych... Nowin... Vprzatnienie..., Vilnius 1620 (two editions); reprint [in:] Collected Works of Meletij Smotryc 'kyj, with an Introduction by David A. Frick, Cambridge 1987 (Harvard Library of Early Ukrainian Literature. Texts, vol. 1).

Woyna-Orański Pachomiusz, Zwierciadto albo zasłona ... naprzeciw uszczypliwej Perspektywie ks. Kassiana Sakowicza..., Vilnius 1645.

Secondary sources

Andrusiak M., Sprawa Patriarchatu Kijowskiego za Władystawa IV [The Case of the Kiev Patriarchate Under Ladislaus IV], [in:] Prace historyczne w 30-lecie dziatalności profesorskiej S. Zakrzewskiego [Historical Papers on the $30^{\text {th }}$ Anniversary of the Professorial Activity of S. Zakrzewski], Lviv, Nakładem Komitetu byłych uczni z zasiłkiem Ministerstwa W.R.i.O.P, 1934, pp. 271-285.

Bobryk W., Duchowieństwo unickiej diecezji chetmskiej w XVIII wieku [The Clergy of the Uniate Diocese of Chełm in the $18^{\text {th }}$ Century], Lublin, Towarzystwo Instytutu Europy Środkowo-Wschodniej, 2005, 217 pp.

Ciołka D., Latynizacja Kościoła unickiego w Rzeczypospolitej po synodzie zamojskim [The Latinization of the Uniate Church in the Polish-Lithuanian Commonwealth After the Synod of Zamość], Białystok, Libra Wydawnictwo i Drukarnia, 2014, 320 pp.

Czupryk R., Unia brzeska: dzieło kościelnej jedności: retrospekcja historyczna [The Union of Brest: The Endeavor of Ecclesiastical Unity: Historical Retrospective], Sandomierz, Rzeszów, Rafał Czupryk, 2015, 153 pp.

Dmitriev M. V., Mezhdu Rimom i Tsar'gradom. Genezis Brestskoi tserkovnoi unii 1595-1596 gg. [Between Rome and Tsargrad. The Genesis of the Brest Church Union 1595-1596], Moscow, Moscow University Press, 2003, 320 pp. 
Dobrowolski R., Zemło M. (Eds.), Dziedzictwo unii brzeskiej [The Legacy of the Union of Brest], Lublin, Supraśl, Wydawnictwo KUL, Collegium Suprasliense, 2012, 424 pp.

Fedoriv Iu., Zamois'kyi synod 1720 r. [The Synod of Zamość 1720], (Vydannia „Bohoslovii”), Rim 1972; the same: "Bohosloviia” 35 (1971), pp. 5-71.

Gudziak B. A. Kryzys i reforma. Metropolia kijowska, patriarchat Konstantynopola i geneza unii brzeskiej [Crisis and Reform: The Kyivan Metropolitanate, the Patriarchate of Constantinople, and the Genesis of the Union of Brest], trans. H. Leskiw, A. Chrin, Lublin, Wydawnictwo Uniwersytetu Marii Curie-Skłodowskiej, 2008 [Eng. issue: Cambridge (Mass.) 1998], 512 pp.

Hodana T., Między królem a carem. Moskwa w oczach prawosławnych Rusinów obywateli Rzeczypospolitej [Between the King and the Tsar. Moscow in the Eyes of Orthodox Rusyns - Citizens of the First Polish Republic], Kraków, Wydawnictwo "Scriptum", 2008, 262 pp.

Hryniewicz W., Przeszłość zostawić Bogu. Unia i uniatyzm w perspektywie ekumenicznej [Leave the Past to God. The Union and Uniatism in the Ecumenical Perspective], Opole, Wydawnictwo Świętego Krzyża, 1995, 174 pp.

Krochmal A., Nowak A. (Eds.), Unia brzeska i jej konsekwencje. W 420 rocznice synodu unijnego [The Union of Brest and Its Consequences. On the $420^{\text {th }}$ Anniversary of the Union Synod], Przemyśl, Archiwum Państwowe, 2017, $353 \mathrm{pp}$.

Łużny R., Adama Hipacego Pocieja "Parenetica". Z nowych odczytań najdawniejszej ruskiej literatury religijno-polemicznej ["Parenetica" by Adam Hipacy Pociej. From New Interpretations of the Most Ancient Ruthenian Religious and Polemical Literature], [in:] Unia brzeska: geneza, dzieje: geneza, dzieje i konsekwencje $w$ kulturze narodów stowiańskich [The Union of Brest: Origins, History...], R. Łużny, F. Ziejka and A. Kępiński (Eds.), Kraków, Wydawnictwo Universitas, 1994, , pp. 346-348.

Łużny R., Księdza Piotra Skargi SJ widzenie Wschodu chrześcijańskiego [Rev. Piotr Skarga's SJ Vision of the Christian East], [in:] Polska - Ukraina: 1000 lat sqsiedztwa, vol. 2. Studia z dziejów chrześcijaństwa na pograniczu kulturowym $i$ etnicznym [Poland - Ukraine: 1000 Years of Neighbourliness, vol. 2. Studies in the History of Christianity on Cultural and Ethnic Borderlands], S. Stępień (Ed.), Przemyśl, Południowo-Wschodni Instytut Naukowy, 1994, pp. 69-75.

Łużny R., Metropolita Piotr Mohyła - człowiek na pograniczu kulturowym grecko-stowiańskim i łacińsko-polskim, [Metropolitan Peter Moghila - the Man on the Cultural Frontier: Greek-Slavic and Latin-Polish], [in:] Acta Polono-Ruthenica I, A. Bartoszewicz (Ed.), Olsztyn, Uniwersytet Warmińsko-Mazurski w Olsztynie, 1996, pp. 333-348. 
Łużny R., Ziejka F., Kępiński A. (eds.), Unia brzeska: geneza, dzieje i konsekwencje w kulturze narodów stowiańskich [The Union of Brest: the Genesis, History and Consequences in the Culure of Slavonic Nations], Kraków, Wydawnictwo Universitas, 1994, pp. 555.

Melnyk M. (Ed.), Unia brzeska: wybór źródet [The Union of Brest: Selected Sources], trans. M. Melnyk, W. Pilipowicz, Olsztyn, Katedra Aksjologicznych Podstaw Edukacji. Wydział Nauk Społecznych. Uniwersytet Warmińsko-Mazurski, 2016, $140 \mathrm{pp}$.

Mironowicz A., Podlaskie ośrodki i organizacje prawosławne w XVI i XVII wieku [Orthodox Centers and Organizations in Podlasie in the $16^{\text {th }}$ and $17^{\text {th }}$ Century], Białystok, Dział Wydawnictw Filii UW, 1991, 301 pp.

Mironowicz A., Piotr Mohyła a idea unii kościelnej [Piotr Mohyła and the Idea of a Church Union], "Studia Podlaskie" XI, Białystok 2001, pp. 25-34.

Mironowicz A., Prawostawie i unia za panowania Jana Kazimierza [Orthodoxy and the Union Under the Reign of John II Casimir Vasa], Białystok, Orthdruk, 1997, $322 \mathrm{pp}$.

Moskałyk J., Problem zjednoczenia w Kościele kijowskim w I połowie XVII wieku [The Problem of Unification in the Kievan Church in the First Half of the $17^{\text {th }}$ Century], Poznań, Uniwersytet Adama Mickiewicza. Wydział Teologiczny. Redakcja Wydawnictw, 2006, 225 pp.

Naumow A., Święci lokalni w myśli kijowskiej pierwszej połowy XVII wieku [Local Saints in the Kievan Thought of the First Half of the $17^{\text {th }}$ Century], [in:] Ars graeca-Ars latina. Studia dedykowane Prof. A. Różyckiej-Bryzek [Ars graeca - Ars latina. The Studies dedicated to Prof. A. Różycka-Bryzek], Kraków, Wydawnictwo UJ, 2001, pp. 199-206.

Naumow A., Domus divisa. Studia nad literatura ruska w I Rzeczypospolitej [Domus divisa. The Studies in Ruthenian Literature in the First Polish Republic], Kraków, "Collegium Columbinum", 2002, 399 pp.

Naumow A., Język - deklaracja przynależności czy narzędzie? Z dylematów I Rzeczypospolitej [A Language - Declaration of Affiliation or a Tool? From the Dilemmas of the First Polish Republic], [in:] VIII Kolokwium Slawistyczne Polsko-Butgarskie [VIII ${ }^{\text {th }}$ Polish-Bulgarian Slavic Colloquium], M. Walczak-Mikołajczakowa (Ed.), Gniezno, Gnieźnieńska Firma Wydawnicza “TUM”, 2001, pp. 21-34.

Naumow A., Prawostawni święci I Rzeczypospolitej [Orthodox Saints of the First Polish Republic], [in:] Święci w kulturze i duchowości dawnej $i$ wspótczesnej Europy [Saints in the Culture and Spirituality of Ancient and Modern Europe], W. Stępniak-Minczewa, Z.J. Kijas (Eds.), Kraków, Wydawnictwo Naukowe PAT, 1999, pp. 21-30. 
Naumow A., Święty Mikołaj w Bari jako argument w polemice wyznaniowej [Saint Nicholas of Bari as an Argument in Religious Polemics], [in:] Instaurare omnia in Christo. O zbawieniu, teologii, dialogu i nadziei. Profesorowi Wacławowi Hryniewiczowi OMI w 70. rocznice urodzin [Instaurare omnia in Christo. On Salvation, Theology, Dialogue and Hope. To Professor Wacław Hryniewicz OMI on His $70^{\text {th }}$ Birthday], P. Kantyka (Ed.), Lublin, Wydawnictwo KUL, 2006, pp. 577-589.

Naumow A., Święci Cyryl i Metody w polemice wyznaniowej [Saint Cyril and Methodius in Religious Polemics], [in:] Środkowoeuropejskie dziedzictwo cyrylo-metodiańskie. Międzynarodowa konferencja naukowa [The Central European Cyrillo-Methodian Legacy. International Scientific Conference], A. Barciak (Ed.), Katowice, Societas Scientiis Silesiae Superioris - Instytut Górnośląski, 1999, pp. 173-184.

Nikolov A., Mezhdu Rim i Konstantinopol. Iz antikatolicheskata literatura v B"lgariia i slavianskiia pravoslaven sviat (XI-XVII v.) [Between Rome and Constantinople. The Anti-Catholic Literature in Bulgaria and the Slavic Orthodox World $\left(11^{\text {th }}-17^{\text {th }} \mathrm{c}.\right)$ ], Sofiia, Fondatsiia “B”lgarsko istorichesko nasledstvo", 2016, $353 \mathrm{pp}$.

Nowakowski P. (ed.), Dziedzictwo Synodu Zamojskiego 1720-2020. Wyzwania i perspektywy [The Legacy of the Synod of Zamość 1720-2020. Challenges and Prospects], Kraków, Wydawnictwo Avalon, 2021, 352 pp.

Nowakowski P., Problematyka liturgiczna w międzywyznaniowej polemice po unii brzeskiej (1596-1720), seria Biblioteka Ekumenii i Dialogu, vol. 23, Kraków, Wydawnictwo Naukowe PAT, 2004, 304 pp.

Stradomski J., Spor „Rusi s Rus'iu” o tserkovnoi skhizme v religioznoi polemike Rechi Pospolitoi XVI-XVII vv. [The "Rus' with Rus"” Dispute over Ecclesiastical Schism in the Religious Polemics of the Polish-Lithuanian Commonwealth in the $16^{\text {th }}-17^{\text {th }}$ Centuries [in:] Religiia $i$ Rus,$X V-X V I I I v v$. [Religion and Russia from the Fifteenth to Eighteenth Century],A.V.Doronin(Ed.), Moscow, ROSSPEN, 2020, pp. 341-351.

Stradomski J., Spór o historię i wartości w świetle katolicko-unicko-prawostawnej polemiki religijnej w Pierwszej Rzeczypospolitej (koniec XVI-poczatek XVIII wieku) [The Dispute About the History and Values in the Catholic-UniateOrthodox Religious Polemics in the Polish-Lithuanian Commonwealth (the End of $16^{\text {th }}$ - the Begining of $18^{\text {th }}$ Century), [in:] Między Wschodem a Zachodem. Prawostawie i unia [Between East and West. Orthodoxy and Union], red. M. Kuczyńska, Warszawa, Wydawnictwa Uniwersytetu Warszawskiego, 2017, pp. 238-276. 
Stradomski J., Spory o ,wiare greckq” w dawnej Rzeczypospolitej [Disputes on the "Greek faith" in the Old Polish Republic], Kraków, Wydawnictwo "Scriptum", 2003, 341 pp.

Tretiak J., Piotr Skarga $w$ dziejach i literaturze unii brzeskiej [Piotr Skarga in the History and Literature of the Union of Brest], Kraków, Akademia Umiejętności, 1912, 352 pp.

Tymoshenko L., Beresteis'ka uniia $1596 r$. [The Brest Union 1596], Drogobych, Drohobych Ivan Franko State Pedagogical University, 2004, 197 pp.

Zema V., Florentijs 'ka unija ta avtokefalija Cerkvy [The Florentine Union and the Autocephaly of the Church], "Ukrainian Historical Journal" 2003, vol. 1, pp. 5367.

Zema V., Mizh apokryfom ta istoriieiu (Florentiis'ka uniia v pravoslavnii polemitsi) [Between Apocrypha and History (The Florentine Union in the Orthodox Dispute)], [in:] A se ieho srebro. Zbirnyk prats' na poshanu chlena-korespondenta NAN Ukraïny Mykoly Fedorovycha Kotliara z nahody 70-richchia [And This is His Silver. The Collection of Works in Honour of the Corresponding Member of the NAS of Ukraine Mykola Fedorovych Kotlyar on the Occasion of the $70^{\text {th }}$ Anniversary], Kiev, Instytut Istorii' Ukrai'ny NAN Ukrai'ny, 2002, pp. 207-224. 
